Ling Ma*, Ruoqi Yang and Jianqing Li

\title{
The crystal structure of $6,6^{\prime}-\left(\left(1 E, 1^{\prime} E\right)\right.$-hydrazine- 1,2-diylidenebis(methaneylylidene)) bis(2-bromo-4-nitrophenol) - dimethylsulfoxide (1/2), $\mathrm{C}_{14} \mathrm{H}_{8} \mathrm{Br}_{2} \mathrm{~N}_{4} \mathrm{O}_{6} \cdot 2\left(\mathrm{C}_{2} \mathrm{H}_{6} \mathrm{OS}\right)$
}

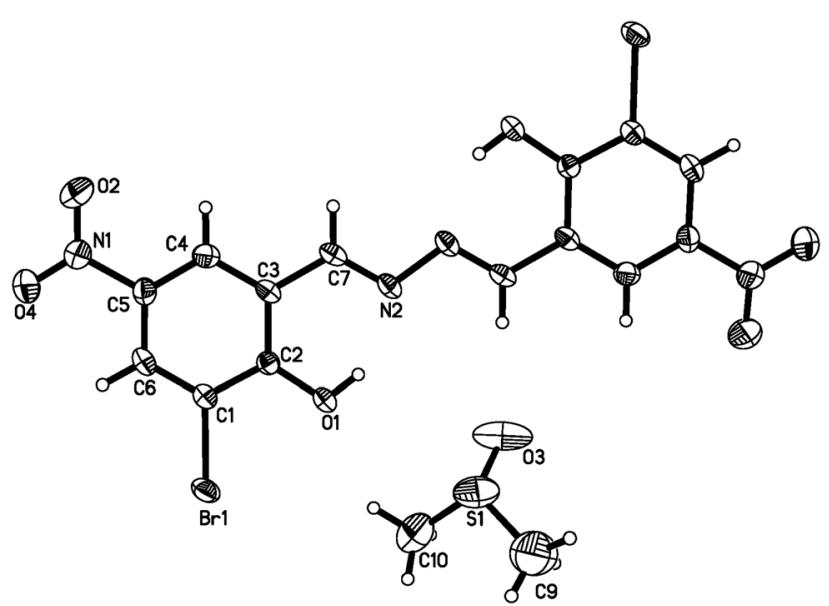

https://doi.org/10.1515/ncrs-2021-0079

Received March 2, 2021; accepted March 18, 2021;

published online April 8, 2021

\section{Abstract}

$\mathrm{C}_{14} \mathrm{H}_{8} \mathrm{Br}_{2} \mathrm{~N}_{4} \mathrm{O}_{6} \cdot 2\left(\mathrm{C}_{2} \mathrm{H}_{6} \mathrm{OS}\right.$ ), triclinic, $P \overline{1}$ (no. 2), $a=6.1463(12) \AA$, $b=8.3637(16) \AA, c=12.461(3) \AA, \alpha=85.578(5)^{\circ}, \beta=85.942(5)^{\circ}$, $y=86.310(5)^{\circ}, V=635.9(2) \AA^{3}, Z=1, R_{g t}(F)=0.0601$, $w R_{\text {ref }}\left(F^{2}\right)=0.0983, \mathrm{~T}=296 \mathrm{~K}$.

\section{CCDC no.: 2057510}

Table 1 contains crystallographic data and Table 2 contains the list of the atoms including atomic coordinates and displacement parameters.

\footnotetext{
*Corresponding author: Ling Ma, Department of Chemistry and Chemical Engineering, Jinzhong University, Jinzhong, Shanxi 030619, P. R. China, E-mail: maling@jzxy.edu.cn. https://orcid.org/00000003-2536-5500

Ruoqi Yang and Jianqing Li, Department of Chemistry and Chemical Engineering, Jinzhong University, Jinzhong, Shanxi 030619, P. R. China
} Ә Open Access. ๑ 2021 Ling Ma et al., published by De Gruyter. ((c)) BY License.
Table 1: Data collection and handling.

\begin{tabular}{ll}
\hline Crystal: & Yellow block \\
Size: & $0.30 \times 0.25 \times 0.20 \mathrm{~mm}$ \\
Wavelength: & Mo $K \alpha$ radiation $(0.71073 \AA)$ \\
$\mu:$ & $3.40 \mathrm{~mm}^{-1}$ \\
Diffractometer, scan mode: & Bruker photon $100, \varphi$ and $\omega$ \\
$\theta_{\max }$, completeness: & $26.4^{\circ},>99 \%$ \\
$N(h k l)_{\text {measured }}, N(h k l)_{\text {unique }}, R_{\text {int }}:$ & $8435,2602,0.068$ \\
Criterion for $I_{\text {obs }}, N(h k l)_{\mathrm{gt}}:$ & $I_{\text {obs }}>2 \sigma\left(I_{\text {obs }}\right), 1586$ \\
$N(\text { param })_{\text {refined }}:$ & 167 \\
Programs: & Bruker $[1,2]$, SHELX [3, 4] \\
\hline
\end{tabular}

\section{Source of materials}

All chemicals were analytical reagent grade and used without further purification. The title compound was prepared according to the synthetic route as following. Into a $100 \mathrm{~mL}$ round-bottom flask with a reflux condenser, 3-bromo-5-nitro-2-hydroxybenzaldehyde $\quad(10 \mathrm{mmol}$, $2.4668 \mathrm{~g}$ ) were dissolved in $40 \mathrm{~mL}$ ethanol and added hydrazine hydrate $(1 \mathrm{mmol}, 60 \mu \mathrm{L})$ into it, refluxing $2 \mathrm{~h}$ later, the pale yellow precipitate of the compound was obtained (yield 89\%). A few days later, yellow block crystals were obtained from DMSO. ${ }^{1} \mathrm{H}$ NMR $(600 \mathrm{MHz}$, DMSO-d $_{6}$ ) (ppm): $9.262(\mathrm{~s}, 2 \mathrm{H},-\mathrm{HC}=\mathrm{N}-)$, 8.658 (s, 2H, Ph$\mathrm{H}), 8.551(\mathrm{~s}, 2 \mathrm{H}, \mathrm{Ph}-\mathrm{H})$.

\section{Experimental details}

Data integrations were performed by the SAINT program [1], and the absorption data were modified by using the multiscan program SADABS [2]. Structural solutions and refinements were performed by using the SHELXS [3] and SHELXL programs [4]. The $\mathrm{H}$ atoms attached to $\mathrm{C}$ atoms were placed in calculated idealized positions and refined by a riding model. 
Table 2: Fractional atomic coordinates and isotropic or equivalent isotropic displacement parameters $\left(\AA^{2}\right)$.

\begin{tabular}{|c|c|c|c|c|}
\hline Atom & $x$ & $y$ & $z$ & $U_{\text {iso }}{ }^{*} / U_{\text {eq }}$ \\
\hline $\mathrm{Br} 1$ & $0.80364(7)$ & $0.88181(6)$ & $0.37022(4)$ & $0.0516(2)$ \\
\hline $\mathrm{S} 1^{\mathrm{a}}$ & $0.1498(8)$ & $0.7024(7)$ & 0.1549 (4) & 0.098 \\
\hline$S 1 A^{b}$ & $0.2235(6)$ & $0.6030(5)$ & 0.0933 & $0.1053(17)$ \\
\hline 03 & $0.1045(10)$ & $0.5372(6)$ & $0.1930(4)$ & $0.149(2)$ \\
\hline N1 & $0.6809(8)$ & $0.8227(6)$ & $0.7922(4)$ & 0.0699 (13) \\
\hline 01 & $0.3997(5)$ & $0.7028(4)$ & $0.3952(2)$ & 0.0489 (8) \\
\hline $\mathrm{H} 1$ & 0.297260 & 0.643909 & 0.401273 & $0.073^{\star}$ \\
\hline N2 & $0.0921(5)$ & $0.5454(4)$ & $0.4953(3)$ & $0.0393(9)$ \\
\hline 02 & $0.5654(7)$ & $0.7917(6)$ & $0.8726(3)$ & $0.1033(15)$ \\
\hline 04 & $0.8570(7)$ & 0.8809 (5) & $0.7921(3)$ & 0.1037 (15) \\
\hline $\mathrm{C} 1$ & $0.6473(7)$ & $0.8123(5)$ & $0.4991(4)$ & $0.0378(11)$ \\
\hline$C 2$ & $0.4607(6)$ & $0.7271(5)$ & $0.4921(3)$ & $0.0338(10)$ \\
\hline C3 & $0.3478(6)$ & $0.6703(5)$ & $0.5883(3)$ & $0.0363(11)$ \\
\hline $\mathrm{C} 4$ & $0.4199(7)$ & $0.7021(5)$ & $0.6864(4)$ & $0.0428(11)$ \\
\hline H4 & 0.344511 & 0.666738 & 0.750255 & $0.051^{*}$ \\
\hline C5 & $0.6048(7)$ & $0.7866(5)$ & $0.6891(4)$ & $0.0453(12)$ \\
\hline C6 & $0.7191(7)$ & $0.8418(5)$ & 0.5959 (4) & $0.0427(12)$ \\
\hline H6 & 0.843601 & 0.898375 & 0.599224 & $0.051^{*}$ \\
\hline C7 & $0.1569(6)$ & $0.5777(5)$ & $0.5845(4)$ & $0.0388(11)$ \\
\hline $\mathrm{H} 7$ & 0.081932 & 0.541919 & 0.648422 & $0.047^{*}$ \\
\hline C9 & $0.0650(12)$ & $0.7526(11)$ & $0.0366(7)$ & $0.170(4)$ \\
\hline H9A & 0.110755 & 0.669922 & -0.010857 & $0.255^{\star}$ \\
\hline $\mathrm{H} 9 \mathrm{~B}$ & 0.125301 & 0.851714 & 0.008777 & $0.255^{\star}$ \\
\hline $\mathrm{H} 9 \mathrm{C}$ & -0.091628 & 0.766109 & 0.041511 & $0.255^{\star}$ \\
\hline C10 & $0.4294(12)$ & $0.7151(10)$ & $0.1345(5)$ & 0.143 (3) \\
\hline $\mathrm{H} 10 \mathrm{~A}$ & 0.490694 & 0.724014 & 0.202445 & $0.215^{\star}$ \\
\hline H10B & 0.460538 & 0.808077 & 0.087158 & $0.215^{\star}$ \\
\hline $\mathrm{H} 10 \mathrm{C}$ & 0.492417 & 0.620443 & 0.102721 & $0.215^{\star}$ \\
\hline
\end{tabular}

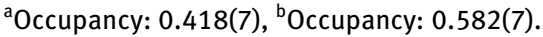

\section{Comment}

Salicylaldehyde azine (SAA) consists of salicylaldehyde and hydrazine, is a Schiff base with ESIPT process and its derivatives exhibit obvious aggregation-induced emission (AIE) characters with recognizable fluorescence performance which have been used widely in bioimaging and ions detection [5, 6]. Different SAA derivatives with specific spectral properties can be obtained $[7,8]$. In this report a SA derivative, named 3-bromo-2-hydroxy-5-nitrobenzaldehyde which has an electron drawing group $\left(-\mathrm{NO}_{2}\right)$ para to the hydroxyl group, was chosen to study the fluorescence properties and we got the crystal structure of the title compound unexpectedly.

The single-crystal X-ray diffraction revealed that title compound crystallized in the triclinic space group and it contains one dimethylsulfoxide (DMSO) molecule and one half of the hydrazine compound in the asymmetric unit. The aromatic carbon-carbon bond lengths deviate significantly, that the values of the $\mathrm{C}(3)-\mathrm{C}(4)$ and $\mathrm{C}(1)-\mathrm{C}(6)$ bonddistances are 1.380(6) and 1.359(6) $\AA$ respectively, which are shorter than the values of the remaining bond distances $[9,10]$. The length of double bond C(7)-N(2), 1.261(5) $\AA$, is very consistent with the value of 1.259(5) $\AA$ given by Safin for the length of carbon-nitrogen double bond of $N, N^{\prime}$-bis (5-bromosalicylidene)diamines [10]. The two benzene rings are in trans configuration connected by N2-N2A bond, and are nearly coplanar (C6-C1-C2-01: 179.9(4) , O1-C2-C3$\mathrm{C} 7: \quad 1.2(6)^{\circ}, \quad \mathrm{C} 3-\mathrm{C} 7-\mathrm{N} 2-\mathrm{N} 2 \mathrm{~A}: \quad 179.5(4)^{\circ}, \quad \mathrm{C} 4-\mathrm{C} 3-\mathrm{C} 7-\mathrm{N} 2$ : $178.6(4)^{\circ}$. In addition, there are weak interactions in the structure. Firstly, the intramolecular $\mathrm{O} 1-\mathrm{H} 1 \cdots \mathrm{N} 2$ hydrogen bonds form a six-membered ring, generating a $S(6)$ ring motif [11]. Secondly, $\pi \cdots \pi$ interactions between aromatic rings are also contained in the structure. The molecules are nearly planar and are arranged in parallel packing, meanwhile the distance between atom $\mathrm{N} 2$ and $\mathrm{Cg}(\mathrm{C} 1-\mathrm{C} 2-\mathrm{C} 3-\mathrm{C} 7-$ $\mathrm{Br} 1-\mathrm{O} 1-\mathrm{N} 2)$ is $3.33 \AA$.

Author contributions: All the authors have accepted responsibility for the entire content of this submitted manuscript and approved submission.

Research funding: Research Fund for Construction Plan of '1331 Engineering' Fluorescent Probe Team (jzxycktd2019038) and the National Natural Science Foundation of China (Grant no. 21671124).

Conflict of interest statement: The authors declare no conflicts of interest regarding this article.

\section{References}

1. Bruker. SAINT; Bruker AXS Inc.: Madison, Wisconsin, USA, 2012.

2. Bruker. SADABS; Bruker AXS Inc.: Madison, Wisconsin, USA, 2001.

3. Sheldrick G. M. A short history of SHELX. Acta Crystallogr. 2008, A64, 112-122.

4. Sheldrick G. M. Crystal structure refinement with SHELXL. Acta Crystallogr. 2015, C71, 3-8.

5. Lu W., Chen J. C., Shi J. Z., Xu L., Yang S. L., Gao B. H. A novel quinoline-based turn-on fuorescent probe for the highly selective detection of $\mathrm{Al}(\mathrm{III})$ and its bioimaging in living cells, plants tissues and zebrafsh. J. Biol. Inorg. Chem. 2021; https://doi.org/10.1007/ s00775-020-01836-6.

6. Gupta A. S., Paul K., Luxami V. A fluorescent probe with "AIE + ESIPT" characteristics for $\mathrm{Cu}^{2+}$ and $\mathrm{F}^{-}$ions estimation. Sens. Actuators B 2017, 246, 653-661.

7. Guo S. W., Song Y. S., He Y. L., Hu X. Y., Wang L. Y. Highly efficient artificial light-harvesting systems constructed in aqueous solution based on supramolecular self-assembly. Angew. Chem. Int. Ed. 2018, 57, 3163-3167. 
8. Chai J., Wu Y. B., Yang B. S., Liu B. The photochromism, light harvesting and self-assembly activity of a multi-function Schiffbase compound based on the AIE effect. J. Mater. Chem. C 2018, 6, 4057-4064.

9. Arcovito G., Bonamico M., Dornenicano A., Vaciago A. Crystal and molecular structure of salicylaldehyde azine. J. Chem. Soc. B 1969, 733-741; https://doi.org/10.1039/j29690000733.
10. Safin D. A., Robeyns K., Garcia Y. Solid-state thermo- and photochromism in $N, N^{\prime}$-bis(5-X-salicylidene)diamines (X $=\mathrm{H}, \mathrm{Br}$ ). RSC Adv. 2012, 2, 11379-11388.

11. Wang L., Su Q., Wu Q. L., Gao W., Mu Y. Synthesis of new substituted benzaldazine derivatives, hydrogen bonding-induced supramolecular structures and luminescent properties. C. $R$. Chimie 2012, 15, 463-470. 